\title{
Research Drying Process with Herbal Gelio Accumulation Drying Equipment
}

Jasur Safarov*

Bukhara Engineering and Technological Institute, Bukhara, Republic of Uzbekistan

\begin{abstract}
In this paper we consider the types of helio dryer for drying materials of plant origin. On the basis of literary analysis of one of the main disadvantages of the drying equipment is a large labor intensity mounting and operation of the equipment. Currently drying medicinal plants performed naturally. It is associated with a significant low quality of the finished product, so the need to develop a new drying equipment and technology. Researchers from Tashkent state technical university have developed a mini-gelio accumulation drying apparatus for producing high-quality products from medicinal herbs. The result of the comparative analysis of different types of dryers gelio has shown that their use contributes to a significant reduction in drying time by accumulation of energy as compared to the natural drying, at the same time preserves the biological active substances in the dried product. Also, discussed characteristics of motherwort (Leonurus cardiaca). The developers conducted an experiment on mini gelio drying equipment. Recycling motherwort (Leonurus cardiaca) should be implemented in the following stages: reception of products, inspection, cutting, drying, grinding. During the drying process, experiments were conducted at a temperature of $45^{\circ} \mathrm{C}$ to $50^{\circ} \mathrm{C}$ and the drying time lasted 6 hours.
\end{abstract}

Keywords: Drying; Medicinal herbs; Gelio accumulation; Drying equipment; Motherwort

\section{Introduction}

As the object of drying the medicinal herbs are composed of more water than dry substances. Total $5 \%$ to $8 \%$ of the water is held tightly, as it relates to cellular colloids, the main part of the water is in a free state. This may explain the slight drying of medicinal herbs raw materials to a moisture content of $10 \%$ to $12 \%$, as well as the difficulty in removing the remaining moisture. Babaev and Volshanik [1] describes a solar dryer greenhouse type, consisting of a supporting brick pillars with purlins, rafters which are laid at an angle of $20^{\circ} \mathrm{C}$ to the horizon. The collected raw material, the last preliminary processing, expanded on the grid at the rate of $10 \mathrm{~kg}$ of raw material per $1 \mathrm{~m}^{2}$ of surface and injected under glass, where is the drying process. One of the main disadvantages in this construction is its large labor input of installation and plant operation. Omarov [2], the results of research on dried fruit in a similar, above drying equipment. Comparative analysis of various types of dryers helio has shown that their use contributes to a significant reduction in the drying time compared to the natural drying, simultaneously with a high quality finished product [3].

Petukhov [4] describes a small combination a dryer for materials of plant origin with the additional the air heater. However, issues such as the determination of the optimal mode exploitation of of solar drying equipment and techno-economic characteristics of the proposed facility in the works have not been considered. Chemical composition of raw vegetable contains proteins, fats, carbohydrates and lipids, as well as plant material has capillary-porous structure. The biologically active substances (BAS), as vitamins, polyphenols, organic acids and minerals contained in small amounts, they are responsible for the flavor and biological value. These components are more susceptible to adverse movements in, which leads to a decrease in the biological value of the final product in the preparation of material for drying in the drying process [5-7].

\section{Motherwort (Leonurus cardiaca)}

External signs: The upper parts of the stems up to $40 \mathrm{~cm}$ with flowers and leaves. The stem is quadrangular, hollow, with thickness up to $0.5 \mathrm{~cm}$. The leaves are opposite, the lower three-five lobes or separate, the inflorescences lobed or lanceolate, toothed or entire, wedge-shaped base with a length of $14 \mathrm{~cm}$, width $10 \mathrm{~cm}$. Inflorescences spicate, interrupted; flowers and buds collected in whorls at 10-18 (20) in the axils of leaves, calyx tubular-campanulate with five teeth subulatepointed, conical, barbed. Corolla up to $0.12 \mathrm{~cm}$, two-lipped, as long as calyx, upper lip entire, the lower three-blade; stamens 4; ovary lower. Stems, leaves and calyx downy hairs [8,9]. Color grayish-green stems, leaves - dark green, the sepals - green, corolla - dirty-pink or pinkishpurple. The smell is weak. Taste bitter.

Microscopy: When considering the sheet surface are visible on both sides with thin epidermal cells of vilistnymi sidewalls, especially at the bottom side. The stomata are numerous, are located mainly in the lower epidermis, surrounded by - 3-4 (rarely 2) about stomatal cells (anomotsitny type). Lronburg on a short stalk with 4-6 (rarely 8) secretory cells. Hairs in two types: numerous multicellular rough warty, expanded in places cell connections; small capitate hairs on the onetwo-cell short stem with a rounded head, consisting of 1-2 cells $[8,9]$.

The numerical indicators: Extractive substances extracted $70 \%$ alcohol none menie $15 \%$, humidity of $13 \%$, ash, total no more than $12 \%$, ash insoluble in $10 \%$ hydrochloric acid solution is not more than $6 \%$, blackened, brownish and yellowish plant parts not more $7 \%$, stalks, including separated in the analysis, no more than $46 \%$ of organic impurities are not more than $3 \%$ of mineral impurities are not more than $1 \%[8,9]$.

The crushed raw material: Extractive substances extracted with $70 \%$ alcohol, none menie $15 \%$, humidity of $13 \%$, ash, total no more than $12 \%$, ash insoluble in $10 \%$ hydrochloric acid, no more than $6 \%$, pochernevshik, brownish and yellowish plant parts max 7\%, no more

*Corresponding author: Jasur Safarov, Bukhara Engineering and Technologica Institute, Bukhara, Republic of Uzbekistan, Tel: +998936587818; E-mail: jasursafarov@yahoo.com

Received December 30, 2016; Accepted January 19, 2017; Published January 25, 2017

Citation: Safarov J (2017) Research Drying Process with Herbal Gelio Accumulation Drying Equipment. J Food Process Technol 8: 654 . doi: 10.4172/2157-7110.1000654

Copyright: (c) 2017 Safarov J. This is an open-access article distributed under the terms of the Creative Commons Attribution License, which permits unrestricted use, distribution, and reproduction in any medium, provided the original author and source are credited. 


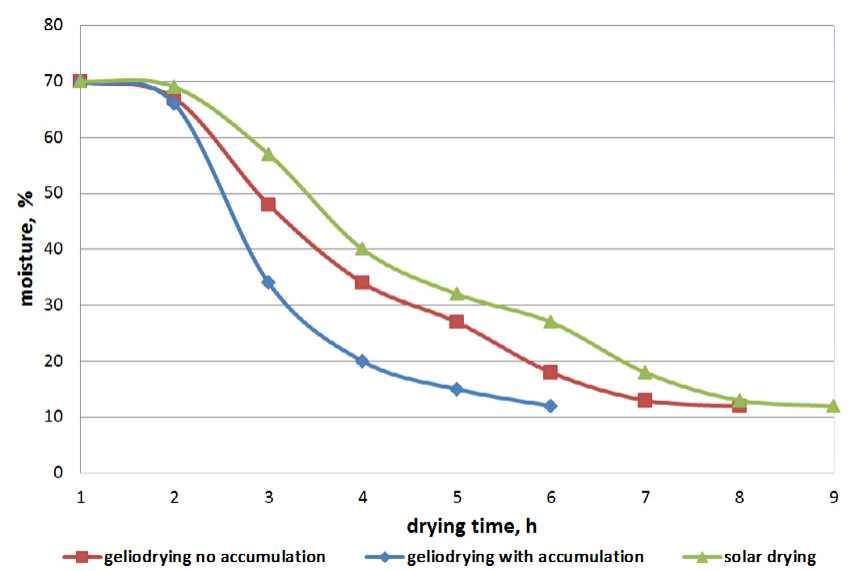

Figure 1: The drying process motherwort (Leonurus cardiaca).

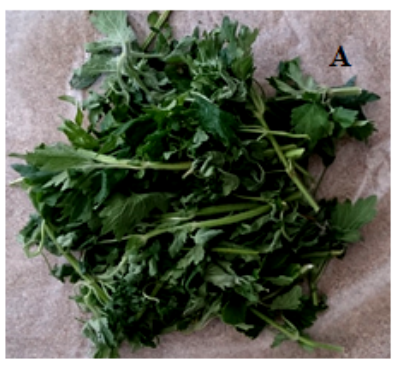

A-before drying; B-after drying.

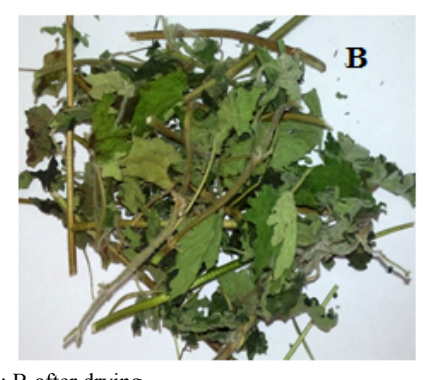

Figure 2: Recycling motherwort (Leonurus cardiaca).

pieces of stems $46 \%$ of particles not passing through a sieve with holes having a diameter of $7 \mathrm{~mm}$, not more than $17 \%$ of particles passing through the sieve with openings of $0.5 \mathrm{~mm}$, no more than $16 \%$ of organic impurities are not more than $3 \%$ mineral impurities are not more than $1 \%[8,9]$.

Pharmacological properties: Motherwort herb has expressed sedative (soothing) properties. Preparations plants have antispasmodic and anticonvulsant effect, slow down the rhythm and increase the strength of heart contractions, have a marked hypotensive and cardiotonic action. Motherwort has a beneficial effect on carbohydrate metabolism and lipid exchange, and decreases glucose levels, lactic and pyruvic acids, cholesterol, total lipids in the blood, protein metabolism normalizes [10].

Chemical composition: The plant contains alkaloids (up 0.4\%): leonurin, leonuridin, stahidrin; choline; sapononiny, flavonoids: quercetin, rutin, kvinkvelozid, kosmosiin, giperozid, quercetin, quercetin -7- glucoside izokvertsitin; iridoids: galiridozid, 8 atsetilgarpagid, ayugozid, ayugol, garpagid; essential oil (0.9\%), which includes limonene, linalool, caryophyllene, $\alpha$-humulene, $\alpha$-and $\beta$-pinene; diterpenoids, steroid glycosides, caffeic acid glycoside, parakumarovaya acid, tannins (2.5\%), bitterness marubin, colorants, resins, vitamin C, carotene; macro- and microelements [10].

\section{Discussion and Conclusion}

At the moment drying herbs performed naturally. It is associated with a significant low quality of the finished product. It is therefore necessary to develop new technologies and drying equipment $[11,12]$. Tashkent state technical university scientists have developed a minihelium accumulation drying equipment for high-quality production of medicinal herbs $[13,14]$. Recycling motherwort (Leonurus cardiaca) should be implemented in the following stages: reception of products, inspection, cutting, drying, grinding.

The developers conducted an experiment on mini gelio drying equipment. During the drying process, experiments were conducted at a temperature of $45^{\circ} \mathrm{C}$ to $50^{\circ} \mathrm{C}$ for 6 hours (Figure 1). With these parameters, motherwort well dried and contained in its structure BAS well preserved. In appearance, it can be determined that the color and the taste is not changed (Figure 2). Thus, the application of solar geliodrying recycled several products occurs in its performance products dryers with accumulation sources of solar energy. In the process of drying experiments were conducted at a temperature of $45^{\circ} \mathrm{C}$ to $50^{\circ} \mathrm{C}$ and the duration of the drying time of 6 hours. With these parameters motherwort well dried and contained in its structure BAS well preserved. In appearance, it can be determined that the color and the taste is not changed.

\section{References}

1. Babaev BD, Volshanik VV (2012) Study of drying materials in gelio dryer for fruits and vegetables. Int Techno-Economic J 2: 76-83.

2. Omarov SK (2004) Varietal, agro-ecological and technological features of drying grapes in Dagestan with gelio dryers: Agricultural Sciences. Makhachkala.

3. Umarov GY, Avezov RR, Ahmadaliev AA (2013) Certain comparative technical and economic indices of the solar drying plant fructo. Solar Technol 5: 59-61.

4. Petukhov BV (1952) Solar energy and its availability. Knowledge.

5. Zhaparov KJ, Chashin VK (2004) Food security of the Republic of Kazakhstan. Food Industry.

6. Campbell K, Campbell T (2013) The results of a large-scale study on the relationship of nutrition and health. Urazaeva: The Chinese study.

7. Kiseleva TF (2007) Drying Technology: Methodical complex. Kemerovo Technological Institute of Food Industry, Kemerovo.

8. USP (1990) State Pharmacopoeia. (11thedn), General methods of analysis Medicine.

9. Ibn-Sina AA (1994) The canon of medicine. Miko Commercial Gazette, FAN Uzbekistan Academy of Sciences, Tashkent.

10. Health (2016) Natural herbal pharmaceutical products.

11. Norkulova KT, Safarov JE (2014) Effect of drying methods on the quality of products from the hips. Storage and processing of agricultural raw materials, Moscow 10: 44-46.

12. Norkulova KT, Safarov JE, Sultanov S, Mamatkulov MM (2015) Design and calculation of accumulative mini-gelio drying equipment. J Food Industry 11: 40-42.

13. Norkulova KT, Safarov JE (2016) Research drying curve of medicinal herbs. J Technical Univer Gabrovo, Bulgariya 53: 3-5.

14. Safarov JE, Tuhtabaev AA, Salohiddinov SR, Saidov ZK (2016) Development geliosushilnoy installations for drying medicinal herbs to the conservation of biological active substances. 